\title{
An Analysis of Students' Perception About Instructional Practices at Post Graduate Level of Allama Iqbal Open University
}

\author{
Farzana Sardar \\ Ph.D. Scholar, Allama Iqbal Open University Islamabad \\ iamfarzana429@gmail.com \\ Dr. Muhammad Ajmal \\ Chairman, Department of DNFE, Allama Iqbal Open University Islamabad \\ drajmal@aiou.edu.pk
}

\begin{abstract}
Instructional practices are one of the fast-changing factors of teaching and learning in today's fast technological development era. These are instructional practices which provide opportunity for better learning and effective relevant material to the learners. The purpose of this study was to analyze the students' perception about instructional practices at post graduate level of Allama Iqbal Open University. This study was descriptive in nature and conducted by using survey with mixed-method approach as well as sequential exploratory design. Focused group discussion ( $\mathrm{N}=12$ ) was conducted during workshop with students' consent. On the basis of focus group discussion, a questionnaire (26 items) was developed on five-point Likert Scale to find out students' perceptions. Content validity was checked through experts' opinion. Sample of N=802 were selected of MPhil and PhD students enrolled at Allama Iqbal Open University in all faculties i.e. Faculty of Sciences, Faculty of Social Sciences and Humanities, Faculty of Arabic and Islamic Studies, Faculty of Education using convenient sampling technique. Survey was conducted to collect the data. Data was analyzed by using statistical techniques of percentage, mean score, $\mathrm{t}$ test, ANOVA (Analysis of Variance). The findings of the study highlighted the importance of instructional practices for open distance learners. Students' perception regarding instructional practices was towards agreement $(M=4.0)$. Students of faculty of Social Sciences and Humanities were found more satisfied as compared to the students of other faculties about instructional practices. The study led to the recommendations regarding instructional practices in different contexts and disciplines across all programs and faculties.
\end{abstract}

Keywords: Instructional Technology, Students Perceptions, Instructional Practices, Post Graduate level student, Open Distance Learning (ODL)

\section{Introduction}

Open Distance Learning (ODL) was started as well as established in late $18^{\text {th }}$ century for imparting facilities of seeking education to those individuals who were not able to get education from traditional and formal system of education. Through ODL system students belonging to any area can obtain an advantage from such kind of learning. Open universities offer chances to such individuals who are not capable to leave their jobs and homes for full time learning. They offer part time educational opportunities through correspondence, tutorials, workshops, television and radio broadcasts and other media of communication.

Open distance learning universities have come forward like a pioneering support for the development of higher education. They reflect diverse clientele and programs. Open and 
distance learning (ODL) institutes have flourished outside the formal system universities (Daniel, 2007). Organizers of ODL have expanded admittance to higher education in many countries and have met large enrollments, following the case of the United Kingdom Open University, founded in 1969 (Moore \&Kearsley, 2012). The function of ODL universities as a path to attaining educational qualifications is vital to their function and worth, whilst also offering mass education in a country. Examples can be quoted of Allama Iqbal Open University of Pakistan, Indira Gandhi National Open University of India, as well as the Open University of China. Moore and Kearsley (2012) have adequately explained the function of open distance education. They are of the view that it has been recognized by the countries that ODL is an influential instrument used for fulfilling the educational and training requirements of a country.

It is vibrant to provide ODL education to the developing country like Pakistan, especially at postgraduate level. It is such a mode of education that has the capacity to meet the needs and challenges of the fast-changing modern global village. UNESCO (2002), Daniel (2007) and Krishnan (2012) identify that it contains the capacity to provide quality education that is also affordable, at all levels as well as in all programs; to the majority of the population, such as males and females, rural and urban residents of the country, and carries the potential to progress the socioeconomic condition of persons as well as their homeland. Pakistan is one of the developing nations of the world which has started to knock the prospective of ODL at the tertiary level.

Tait (2000), Tait and Mills (2002), Dzakiria (2005, 2008), Daniel (2010), and Krishnan (2012) point out that research carried out both in developing and developed nations specify that instructional practices are regarded as to be vital to facilitate ODL learners. Rumble (2000) and Daniel (2010) mentioned that the achievement of students in ODL relies upon the instructional practices. Nonetheless, Simpson $(2000,2002)$ states that in most of the institutes, focus is given to one kind of practices than the other practices. Simpson (2000, 2012), Dzakiria (2005, 2008), De Hart and Venter (2013) notice that a number of students become isolated, frequently drop inspiration, deliver inadequately, furthermore, yet withdraw since they require the vital support which is central to their achievement. Boyd-Barrett (2000), Choudhry, Gujjar and Hafeez (2008), Latif, Sungsri and Bahroom (2009) and Sharma (2011) mention that Allama Iqbal Open University tries to solve the issue of access amongst the learners through providing instructional practices at all levels among all the faculties to the students of each semester irrespective of their gender; in the similar method which other nations inside the developed and developing world have done.

To provide instructional practices is helpful as it facilitates access to the students near to their home places. Instructional practices that include educational as well as non-educational support can be actually contacted via different types of technology like internet, CD, printed material, television and radio. Macintyre and Macdonald (2011) have noted that the development of technology, consequently, has covered the issue of geographical remoteness in ODL system. Nevertheless, within a few portions of the world, mainly in developing regions wherever there is a low level of technology and pitiable infrastructure, provision of suitable instructional practices and the chance to frequently communicate to the peers as well as tutors is crucial. Asunka (2008) suggests that the excellent administration is of the utmost importance to guarantee the ease of access along with ease of use of instructional practices. On the other hand, less resources act as an obstacle to the effectual stipulation of these practices.

Khan (2001), Sahn and Stifel (2003), Gatsha (2008), Sugata (2008), Mbukusa (2009), Aikael (2010), Lephalala and Makoe (2012) identify that the low socioeconomic position of the 
people, insufficient facility of technology along with pitiable infrastructure are responsible for less enrollment at postgraduate level. For ODL students at postgraduate level, there is a need to discover the students' perceptionsfurther minutely about their learning and teaching experiences linked to instructional practices.

In carrying out a broad analysis of the literature on instructional practices the researcher recognized a significant information breach. Bhalalusesa (1998) have searched that a good number of the research studies carried out in the field of ODL have a European reference as well as contain less impact for underdeveloped nations. A small number of accessible work has a propensity to normalize the students' perceptions (Mahai, 2012; Srivastava \& Reddy, 2007).

There is very little investigation up till now on students' perceptions in developing countries. Same is the case in Pakistan especially with reference to Allama Iqbal Open University. Numerous writers like Mcharazo and Olden (2000), Bhalalusesa (2001), Msuya and Maro (2002), Chadibe (2002), Ukpo (2006), Amey and Maroba (2008), Gatsha (2008), Mbukusa (2009), Gatsha and Evans (2010), Lephalala and Makoe (2012), De Hart and Venter (2013) have realized the requirement for further exploration in this field. The aim of the current research work is to add to the existing literature through investigating the perceptions of postgraduate level students at Allama Iqbal Open University and to reflect on the implications of the instructional practices for the university. This study analyses students' perception about instructional practices at postgraduate level of Allama Iqbal Open University. It is particularly important to analyze the students' perception about instructional practices, since these practices perform such a fundamental function in promoting open distance learning.

\section{Statement of the Problem}

Teaching learning process is primarily based on instructional practices of any institution. Instructional practices in open distance learning system are more important as students are at a distance, but there is no way out to find out the feedback of the students regarding the system. Any drawback in instructional process may adversely affect the teaching learning process in ODL system. Therefore, this research study focuses on the investigation of students' perception about instructional practices in open distance learning (ODL) system.

\section{Research Objective}

The following was the objective of this research study:

1. To investigate students' perception about instructional practices at Allama Iqbal Open University.

\section{Research Questions}

Considering the objectives of the study, the following research questions were established to be answered accordingly.

1. What do students perceive about instructional practices at Allama Iqbal Open University?

2. Is there any significant difference in perception among students of different faculties about instructional practices?

\section{Research methodology}

It was a survey research using mixed-method approach. Sequential-exploratory design was applied as the data were not collected concurrently. The sufficient literature was not 
available to identify the factors for instructional practices, a focus group discussion was arranged. On the basis of the findings of the focus group discussion, a questionnaire was developed. Thus, the data for the study was collected using two different surveys; one qualitative and the other quantitative.

This was a descriptive survey research study, mixed-method approach and sequentialexploratory design was applied using convenient sampling technique, focusing on analyzing students' perception about instructional practices, experienced by open distance learners of post graduate (M.Phil. and PhD) level.

A focus group discussion was conducted with the students of M.Phil. and PhD enrolled at AIOU and a survey using a questionnaire. A questionnaire was developed on five-point Likert Scale along with two open ended questions. Data were collected through personal visits. The data were analyzed through descriptive statistics, mean score, $\mathrm{t}$-test and ANOVA. Data were analyzed through SPSS version 16.

\section{Population}

The population of the research study comprised of the students of M.Phil. and PhD students enrolled at Allama Iqbal Open University. They consist of all the M.Phil. and PhD students enrolled inall the four faculties of Allama Iqbal Open University. These four faculties are: faculty of Sciences, faculty of Social Sciences and Humanities, faculty of Arabic and Islamic Studies; and faculty of Education. Total population comprises of 1603M.Phil. and $\mathrm{PhD}$ students enrolled in four faculties in autumn 2015 and spring 2016 at AIOU.

\section{Sample}

Convenient sampling technique was used to select the sample from the population. Total population was 1603 in number and fifty percent of the population was taken as a sample of the study ( $\mathrm{n}=802$ ). Mordkoff (2016) states that it is assumed that the population is normal when we use a sample of more than thirty persons.

\section{Research Instrument}

Data was collected through Focus group discussion and a questionnaire was developed on five-point Likert Scale.

The questionnaire was based on three parts: Demographic information, Five-point Likert Scale, and Open-ended questions

The research instrument was developed on the basis of the focus group discussion. The following major variables and their sub constructs were developed.

Students' perception about distance learning was taken as dependent variable, whereas instructional practices in open distance learning system were taken as independent variables.

\section{Analysis of Focus Group Discussion}

For the focus group discussion, participants were recruited from a matching sample group of students. They were twelve in number. They indicated that they were not able to access most of the instructional practices fully, for one reason or the other, although they placed value to those practices as far as their studies were concerned. The discussions are summarized into the sub factors of practices, after taking into account the literature survey and views of focus group. These are instructional practices which can be further categorized as under: 


\begin{tabular}{ll}
\hline Sub Scales & Key Words \\
\hline Instructional Practices & $\begin{array}{l}\text { Study material, Tutorials/face to face components, } \\
\text { Research Guidance and Supervision, Assignments, } \\
\text { Workshops, Assessments. }\end{array}$ \\
\hline
\end{tabular}

\subsection{Instructional practices}

The following instructional practices were discussed by the participants of FGD:

\section{Study Material}

Participants discussed their feelings about study material, and they reported that sometimes course objectives were not mentioned in course books and sometimes course contents were not in line with course objectives. A prominent subscale of instructional practices was identified in this way. There were also instances in which participants reported that study material was not self-explanatory and was lacking in developing critical thinking. It was also pointed out that course content lacked in cohesion of ideas.

Printed study materials are used as a source of self-teaching material among students at AIOU. One of the participants of FGD said: "We use study material to get academic guidelines...these are the main academic guiding source to ODL learners...objectives keep us on right track...objectives given in the study material keep us on right track". Another one narrated: "It is the matter of utmost importance that course content is in line with the objectives...objectives set direction for the course content...AIOU normally follows this pattern." Another participant added: "Crux of the ODL is that the study materials are selfexplanatory... ODL learners have to work without a teacher... study guides of AIOU are written on this theme...when one reads, one finds them interactive". Similarly, another added: "These study guides help to develop critical thinking...they are thought provoking. At the end of each chapter some questions are set to ponder over... some further articles are also suggested to read". One more participant said: "Cohesion of ideas in these books create a thematic thread that keeps one on the right track". One of the participants of FGD said: "Sometimes course objectives are missing from course contents. It becomes difficult for us to follow the instructions. Need of tutor is always there to follow the study material. Learning outcomes should be given in each course". Similarly, another participant said: "Course contents are not in line with course objectives. It becomes absurd for us to follow these study materials and they lose the concept of selfexplanatory material". Another was of the view: "Study material is not self-explanatory. Sometimes there is lack of cohesion of ideas in it. But we try our best to follow the material". One participant contradicted them and was of the view: "It is helpful in developing critical thinking. It is the best source of concept formation. We get the best out of it. Course objectives are there to provide the guidelines. I find it self-explanatory" Another participant said: "Course objectives are there, and we get guidelines from them, but it is quite difficult to comprehend study material without a tutor. Study materials need to be updated. It should be updated according to the changing needs of the society. One of them said: "Sometimes we find course content is not aligned with the learning outcomes. Anyhow I find study materials selfexplanatory and easy to comprehend". One made such comments: "I highly appreciate the content of the study materials". Another participant also supported him: "these are the best guiding materials". While two others contradicted them saying: "we find ourselves in chaos to 
find it self-explanatory". Yet another participant said: "I am not sure whether learning outcomes are helpful in following the study materials".

\section{Tutorials/Face to Face Component}

Arranged face to face teaching sessions at the AIOU are only available for the students of faculty of science. Proper tutorials or face to face sessions are not arranged for the students of other faculties at postgraduate level. Participants reported that it is difficult to get guidance from their tutors during the assignment writing process. They felt isolation while writing assignments. They also complained that system of assignment marking is dissatisfactory. Sometimes harsh behavior was reported on the part of the tutors by the participants. They also reported about the cheating practice in assignment writing process.

One of the participants said: "Anytime I have a problem I contact them for help, but it is not so simple". Similarly, another participant said: "Tutors are always there to guide us whenever we contact or call them. They are quite helpful to guide us". One of the participants also supported these views and said: "We the students contact our tutors on phone, and they guide us, and I am satisfied with the system of assignment marking. Cheating is not allowed in assignment writing. I always find my tutors polite". Similarly, another participant added: "We are quite satisfied with the assignment system of AIOU. Tutors' behavior is quite satisfactory. At this level we don't need to be too much dependent on tutors". Another participant contradicted and said: "Tutors are not bound to provide guidance as proper tutorials are not scheduled for M.Phil. and PhD students. We have to solve our academic difficulties of our own." One of the participants said: "I am not satisfied with the system of assignment marking as well as the behavior of the tutors. It is quiteillogical system. There is no way to stop cheating in this system". Similarly, another participant added to this point and said: "Tutors treat harshly to the students. They do not consider it their responsibility to guide them as there are no tutorial meetings for us". One of the participants narrated: "Many times we try to contact but fail to get positive feedback. Sometimes we don't know what to do and where to go. You know... we become disappointed". Another reported: "We have problems during assignment writing. Another narrated: "We face harsh behavior of tutors". Still another added: "Tutors don't entertain telephonic calls. We have guidance issues while writing assignments. In manual system students also copy each other's assignments".

Students are not able to contact tutors during the sessions to discuss their academic problems. They are provided with the contact numbers of their concerned tutors as well as their addresses. Obviously, the role of tutor is vital in enabling students to succeed in their studies. In any case, troubles such as transport, distance and money create hindrance for the students to contact their tutors.

\section{Research Guidance and Supervision}

A variety of factors were discussed by the participants who developed trust and positive working relationship with supervisors. Lack of coordination was one of the factors. Respondents objected that they were not given the choice to select the topic of research for their thesis. Also impeding the process of guidance, some supervisors don't provide enough time for discussion. Respondents in this focus group mentioned that there is a need to conduct regular meetings with supervisors.

One of the participants' narrated: "We find coordination from supervisor's side. We are given the choice to select the topic for the research study. We have regular meetings with our supervisor." The other participant also supported this view and said: "Supervisors provide 
enough time for discussion. Topic was selected with the guidance of supervisor. Supervisors call for regular meetings." One of them supported these views and added: "Whenever I contact my supervisor, he guides me open heartedly. I am working on the topic of my own choice." Similarly, another participant said: "My supervisor is very cooperative and helpful in my research. She guides me whenever I contact her. My supervisor guided me in the selection of my topic. I usually meet my supervisor on weekends." One of them said: "I've topic of my own choice. Supervisor herself calls me for meetings. I've never an issue with my supervisor." One of the participants' contradicted and said: "There is less coordination between supervisors and supervisees. We are not free in the selection of topic of our own choice. Whenever I visit the supervisor, he asked me to contact some person in local university for guidance". One of them viewed: "Sometimes we are given the choice to select the topic of research of our own choice...but most of the time it is assigned by the department... what is the purpose of research then? Supervisors are less cooperative."Another participant narrated: "Supervisors are found busy in their office chores...they had less time to guide the researchers. Topic selection is an uphill task for the researchers". One of them viewed: "We need regular meetings with our supervisors... some schedule might be followed. We should be given the chance to work on the topic of our own choice." Another participant added and said: "Usually supervisors have less time to guide. They want that we should work without their help or guidance. They only need readymade material from us. Department imposes the topic of its own interest and choice, this creates hurdle in our research work". In the same way one of them said: "Supervisors are most of the non-cooperative creature for us. They are never helpful for us. They never check our work in progress. It is only in the end that we find ourselves in chaos. Topic selection is another tedious activity".

\section{Assignments}

Assignments are the written exercises which are completed by the students while being at their homes and places of work. They are written after studying their reading material and after attending the course workshop organized by the department. These are designed in a way that students are able to relate their readings with their own objective judgments. The students will send two compulsory assignments for each 3 credit hours course to their tutors who return them after marking and providing necessary feedback.

One of the participants of FGD said: "It is easy for us to attempt assignment questions as they are based on study materials. Tutors are always there to guide us. Assignment questions are usually of practical nature. Study material and internet is the main source of guidance. Sometimes if there is a difficulty in solving these questions, we mutually try to resolve the issue. I think now university has started to check plagiarism through online system. Tutors return the assignments during workshops. The other participant also supported these views and said: "Assignment questions are from study materials. These questions are usually related to some practical issue or some day-to-day life event, but it's not difficult to attempt these questions. Our tutors try to check plagiarism". Similarly, another participant narrated: "Assignment questions are usually of practical nature. Study guides are helpful to attempt these questions, but one does not have to totally rely on study guides. We need to search Google or some internet sources too. We normally get back these assignments from our tutors. We share our assignments with classmates, but plagiarism might be checked by the tutors, I am not sure about it". Still another shared his views: "Assignment questions are usually easy to attempt. They are returned through post. Practical nature of assignment questions makes it really interesting for us. We take it as a challenge for us to cope with such questions. We really enjoy it...! Tutors guide us to avoid 
plagiarism". One of the participants' said: "Practice of assignment writing is the best practice of ODL system. Questions are not so simple; they have the capacity of brainstorming. Study materials are helpful in attempting them but not in a simple way. We have to search for some extra sources too". Some contradictory views were also witnessed. One of them said: "It is a tedious activity to write down assignment. They are normally not based on study materials. Student copy each other's assignments. It is ignored by the department. Some strict actions should be taken, while some of us write them through serious efforts. This is not fair with us. We receive our assignments after duly marked by the tutors". Another supported her views by narrating: "We don't find these assignment questions of practical nature. It is really difficult for us to cope with such questions. Most of the time they are not based on study materials. Copy pasting is so common and there is no way to stop all this practice. Tutors never return assignments". Similarly, one of the participants' said: ODL system of AIOU does not follow the practice of assignment writing in letter and spirit. Students' normally hire or request someone to help them in this practice. Tutors also don't have even a bird's eye view of these writings. Its good if it is shifting towards online submission of assignments, at least plagiarism would be checked". Another participant added: "Assignment questions are usually set out of course. I don't find any practicality in it; rather assignment writing becomes a difficult practice for us. Tutors never guide us. They never return us assignments after marking them. Sometimes we personally go to their office and get them back personally". Still another commented: "Assignment writing in ODL system is not an easy practice. Questions are not from the books sent to us. Most of the questions are found irrelevant. Tutors rarely send back marked assignments". One of them was of the view: "Assignment questions are set in traditional way. They need to be practical in nature. Study materials are not supportive in solving assignment questions. Tutors never send back our assignments. We are never given opportunity to submit assignments online".

Many participants talked that they found assignment questions difficult as they were not based on study guides. They also raised objections on the practical nature of these questions. They also mentioned the need to check the plagiarism of assignments.

The participants also showed their resentment on untimely return of assignments to them.

\section{Workshops}

Workshops are compulsory components for postgraduate students. Almost one-week workshop is arranged for each course in every semester. These sessions are conducted at main campus of AIOU. Resource persons are hired to deliver lectures.

Respondents reported several experiences regarding the subscale workshops of instructional practices. They reported that it was quite difficult for them to attend workshops at the main campus. They were not found satisfied with the resource persons. Other than multimedia they focused that workshops should be arranged through Skype and videoconferencing so that ODL students might be facilitated at their doorsteps. They urged the need of activity-based learning during the workshops. They also complained that workshop sessions should be well planned and online/e-learning methods should be used.

One of the participants' said: "We go to attend workshops at main campus. We have easy access to the venue. Workshop sessions are well arranged and properly managed. University arranges competent resource persons. Resource persons make use of multimedia during workshops. Activity based learning is focused during these sessions. Online learning system is also introduced during these workshops". Another participant supported her views by saying: "Workshops are arranged at the main campus of AIOU. Competent resource persons are hired 
for these sessions resource persons deliver lectures through power point on multimedia. These resource persons usually have command on the topic. They also focus to deliver lectures through activity-based learning". Similarly, one of the participants' reported: "AIOU arranges workshops at main campus. Competent resource persons are arranged for these sessions. Most of the resource persons make use of multimedia during their lectures. Activity based learning is also introduced. These sessions are properly managed. Online learning system is focused during these sessions". Still, another participant said: "Main campus is the venue of all workshops at M.Phil. and $\mathrm{PhD}$ level. We easily approach this venue. Resource persons come prepared to the class. They deliver lectures through multimedia. These sessions are normally well planned". One more participant supported these views by saying: "We enjoy workshop sessions at main campus. This is the source to meet the classmates around the country, you know. Most of the resource persons are well prepared and deliver lectures through multimedia and sessions are well managed. Workshop venue is accessible to us". Another added his views as: "At this level we can travel to main campus for attending well planned workshop sessions in a furnished wellequipped environment, with resource persons using modern technology". Along with positive feedback some of the participants also reported the other side of the picture. Contrarily one of the participants' said: "It is quite difficult to travel and attend sessions at the main campus. All this is not cost effective for us, for which we prefer ODL system. Resource persons share nothing new. Regional campuses can become best venues by video conferencing. Multimedia is not the only source of delivery; other sources should be utilized". Another participant said: "We, the working persons find it hard to attend workshops away from our workplaces. Resource persons are not well versed on their topics. They try to teach in a traditional way, where there is no place of activity-based learning". One more participant added to it by saying: "It is difficult for females to approach workshop venue at main campus. No doubt competent resource persons are available here but through video conferencing access may be provided at regional centers". Similarly, one more participant said: "Workshop venues are not easily approachable for us. What is the purpose to come after travelling from far flinch areas and attend boring, ill managed sessions at the cost of your time, money and work? Sometimes non serious resource persons interact in the class, which is totally the wastage of time. Use of multimedia is rare during these sessions". Another participant said: "Workshop venues are not easily accessible, when we talk about ODL system of AIOU. We were not satisfied with the competency of resource persons. Activity based learning is not focused. Workshop sessions are not well planned for most of the time, even sometimes one feels what a hell what's going on without any purpose". Another participant supported this view by adding: "It was quite difficult for me to attend workshops at the main campus. Use of multimedia is not common during workshops. Workshop sessions go haphazardly. Most of the time we feel it's just wastage of time. Sometimes one has to interact with non-serious resource persons instead of competent ones. Use of multimedia is not so common. Activity based learning is not focused".

These workshop sessions are pre-arranged, and students obtain academic guidance. This was confirmed by a respondent who narrated: "Workshop session is important to see your tutors...you get assistance and guidelines".

The importance of workshop session is finely narrated by Chadibe (2002), Simpson (2002) and Chandran (2011) in the literature because during workshop students interact, exchange their ideas and develop the feelings of belongingness.

\section{Assessments}

Participants discussed a number of factors regarding assessment system in ODL. They 
raised their objection that final examination does not relate to the course contents. They were found quite dissatisfied with the closed book paper and pen examination at this level. They also highlighted that this system encourages cramming in the examination. They also raised their voices that comprehension test was conducted very late after the declaration of the result.

One of the participants' narrated: "Final examinations are based on the course content. It is a good system to evaluate through this system. Usually creative questions are set in the examination paper. I don't think cramming is encouraged in this system. Comprehensive test was conducted well in time". Another participant added: "We are satisfied with this system. Examination questions are usually focused on brain storming. It is not the root cause for cramming. Similarly, another participant said: "Examination system is quite satisfactory. Close paper and pen system is not an objectionable system of exams. We were called for comprehensive exam shortly after completing the course work. This examination system does not encourage rote learning". Adding to these views, another participant further said: "Examination system of AIOU is satisfactory. This system encourages creative writing. Cramming is discouraged in this system". One of the participants' viewed: "Examination system of this university is quite satisfactory. Cramming is not supported in this system, rather it supports creative answers". One of them added: "Examination system encourages creativity. We are satisfied with this system. Rote learning is rare in this system. Some of the participants viewed contrary to these views. One of them argued: "Examination system is tedious one. It is based on traditional system that encourages cramming... Why not introducing online exam system for ODL learners? Examination questions don't relate to course content. Comprehension test was conducted very late". Another participant supported his views by saying: "Examination system of AIOU does not support the ODL learners. It is just like the formal system. There is no way to check cramming. Creativity is discouraged in this system". One more participant showed her resentment strongly by adding: "We get admission in this system to save time and money, but everything is at stake for us. Examination system is much traditional one, which encourages rote learning. If we try to write something in creativity, that is discouraged, we lose our marks. Much time is wasted in conducting comprehension exam". Similarly, another supported these views and said: "What a hell...nothing is innovative in this ODL examination system. It is just following the footsteps of traditional system. Examination questions are mostly set out of course. Closed book and pen system might be replaced at this level". Another participant added by saying: "Final examinations don't relate to the course content. This system of examination encourages cramming. Creativity is nowhere in this system. I'm not satisfied about this examination system". Similarly, another participant supported these views and said: "This examination system is no more practicable in ODL system. It should be replaced with creative writing. Comprehension test needs to be conducted timely. Closed book and pen system should be replaced".

\section{Analysis of Questionnaire for Instructional Practices}

On the basis of focus group discussion, a questionnaire was developed on five-point Likert Scale. The major analysis for instructional practices is presented in the form of the tables as under:

\section{Table 1 Students' perception regarding instructional practices}

This table is showing the means of all the statements related to the instructional practices. 


Statement
Study Material
1 Course objectives/learning outcomes are mentioned
in the course books

2 Course content is aligned with the course $683 \quad 4.50 \quad 1.09$ objectives/learning outcomes

3 Study material is self-explanatory

$\begin{array}{lll}\mathbf{N} & \text { Mean } & \text { SD } \\ 683 & 4.21 & 1.14 \\ & & \\ 683 & 4.50 & 1.09 \\ & & \\ 683 & 3.51 & 1.13 \\ 683 & 4.30 & 1.15 \\ 683 & 4.31 & 1.06 \\ & & \\ 683 & 2.34 & 1.21 \\ & & \\ 683 & 3.21 & 1.24 \\ 683 & 2.31 & 1.21 \\ 683 & 3.13 & 1.38 \\ 173 & 4.21 & 1.23 \\ & & \\ 173 & 3.40 & 1.33\end{array}$

4 Study material is helpful to develop the critical thinking

5 There is a cohesion/unity of ideas in the course content

\section{Tutorials/face to face component}

6 Tutors provide guidance if contacted in case of any difficulty during the assignments

7 System of assignment marking is satisfactory

8 Tutors behave politely with students

9 Cheating is not allowed in assignment writing

\section{Research Guidance and Supervision}

10 I was given the choice to select my own topic of thesis

11 Supervisor provides enough time for thesis discussion

12 Regular meetings are conducted with supervisors for research work

\section{Assignments}

13 Assignment questions are based on study guides and allied material

14 Assignment questions are of practical nature

15 Plagiarism of assignment is checked by the department

16 Assignments are returned timely to the students

17 Workshops venue is easily approachable

18 Resource persons of workshops were well prepared

173

4.31

19 Technology (e.g., multimedia, Skype, videoconferencing) was used during the workshops

20 Activity based learning is ensured during the workshops

21 Workshop sessions are well planned

21 Workshop sessions are well planned

22 Online/E-learning method is used in teaching learning process

\section{Assessments}

23 Final examination relates to the course contents

$683 \quad 3.81 \quad 1.21$

$\begin{array}{lll}683 & 2.80 & 1.23\end{array}$

$\begin{array}{lll}683 & 2.43 \quad 1.24\end{array}$

$\begin{array}{lll}683 & 2.30 & 1.29\end{array}$

$\begin{array}{lll}683 & 3.54 & 1.37\end{array}$

$\begin{array}{lll}683 & 3.51 \quad 1.26\end{array}$

$\begin{array}{lll}683 & 4.00 \quad 1.32\end{array}$

$\begin{array}{lll}683 & 3.07 \quad 1.23\end{array}$

$\begin{array}{lll}683 & 4.49 & 1.22\end{array}$

$\begin{array}{lll}683 & 4.49 & 1.22\end{array}$

$\begin{array}{lll}683 & 4.82 & 1.28\end{array}$

$\begin{array}{lll}513 & 4.72 \quad 1.26\end{array}$ 
24 I am satisfied with closed book paper and pen examination at this level

25 Cramming/rote learning is discouraged in the examination

26 Comprehensive testswere conducted for $\mathrm{PhD}$ students soon after the declaration of the result

$513 \quad 4.87 \quad 1.26$

$513 \quad 2.82 \quad 1.21$

$93 \quad 2.27 \quad 1.28$

$\mathrm{N}=$ number of respondents, $\mathrm{SD}=$ Standard deviation

Table 2 Instructional Practices

\begin{tabular}{lc}
\hline Sub Scales & Mean \\
\hline Study Material & 4.2 \\
Tutorial/Face to face meetings & 2.7 \\
Research Guidance and Supervision & 4.0 \\
Assignments & 2.8 \\
Workshops & 4.0 \\
Assessment & 3.6 \\
Total & 4.0 \\
\hline
\end{tabular}

Table 2 showing the mean score of students' perceptions regarding sub scales study material, tutorial, research guidance and supervision and assignments of instructional practices. This table revealed that perception about the instructional practices is strong on the scales of study material, research guidance and supervision, workshop and somehow assessment. But it is weaker on the scales of tutorials and assignments.

Table 3 Results of open-ended question regarding instructional practices

$\begin{array}{lll}\text { Sub scale } & \text { Suggestions } & f\end{array}$

Study material Study material should be updated and revised according to $\quad 58$ the fast-changing world by keeping in view the needs of ODL learners.

Study material should be provided on time. $\quad 46$

Study material should be accessible online also. $\quad 34$

Tutorials/Face to Small learning groups/peer groups should be developed on 33 face component social media/WhatsApp etc.

Face to face meetings are necessary once a month to meet 33 the needs of ODL students.

Online tutorials and video lectures should be available. $\quad 31$

Lectures should be delivered through multimedia. 30

Computer-mediated discussion and collaborative learning $\quad 28$

activities should be conducted asynchronously.

Collaborative projects, cooperative learning, and

Interactivity within groups of students should be developed.

A televised distant classroom concept should be introduced. 22

Research $\quad$ Selection of a supervisor is an uphill task. 20

guidance and

Supervision 
Supervisors should provide plenty of time to the 20 supervisees when contacted.

Monthly meetings should be arranged between supervisor $\quad 20$ and supervisee.

Researchers should be properly facilitated. $\quad 19$

Supervisors must provide proper guidance to the 17 supervisees.

Tutors should provide feedback to the students, as it is the 13

Assignments only way to improve the assignments.

System of assignment making is not much satisfactory. $\quad 12$

Quality of assignments should be ensured. 11

$\begin{array}{lll}\text { Workshops } & \text { Workshops should be arranged at regional campuses. } & 10\end{array}$

Competent resource persons should be hired during $\quad 7$

workshops.

$\begin{array}{ll}\text { Peer discussions should be encouraged during workshops. } & 7\end{array}$

Presentation should be allowed in any medium. 7

$\begin{array}{lll}\text { Examinations } & \text { Examinations should be merged with assignment writing } \quad 6\end{array}$

system.

Questions in question papers should be comprehendible. 6

Paper pattern should be changed; short questions should be 3 included in the question paper.

The table 3 reveals that majority of the participants (58) stated that study material should be updated and revised according to the needs of fast changing world by keeping in view the needs of ODL students. Some of the respondents (46) said that study material should be provided on time while others (34) demanded that study material should be made accessible online also.

Some respondents (33) asked to develop small learning groups on social media and demanded for face-to-face meeting once a month. Online learning and video lectures through multimedia was also demanded by some of them (31). Cooperative learning, and televised distance classroom was also required by some of them (22).

A few of them (20) narrated the issues regarding the selection of supervisor, nonavailability of time on the part of the supervisors and demanded for monthly meetings with the supervisors. Some of them (19) demanded for facilitation during research work.

Some of them (13) demanded feedback on the assignments and complained about the unsatisfactory system of assignment marking. A few of them (19) demanded that workshops should be arranged at regional campuses. There was also a demand of competent resource persons, peer discussion during workshops and to present presentation in any medium by a few of them (7).

Some of the participants (6) demanded to merge the examination system with assignment writing system or to change the paper pattern.

Table 4 Faculty wise Differences of Students' Perception about Instructional Practices

\begin{tabular}{lccccc}
\hline Instructional Practices & \multicolumn{1}{c}{$\boldsymbol{S}$} & $\boldsymbol{D} \boldsymbol{f}$ & $\boldsymbol{M S}$ & $\boldsymbol{f}$ & $\boldsymbol{p}$ \\
\hline Between Groups & 4.390 & 3 & 1.463 & $2.676^{*}$ & .046 \\
Within Groups & 371.299 & 679 & .547 & & \\
Total & 375.689 & 682 & & & \\
\hline
\end{tabular}

$*$ Significant $(\mathrm{P}<0.05)$ 
In table 4, One-way Analysis of Variance (ANOVA) was performed to find out faculty wise difference of perception of students regarding instructional practices. The participants were divided into four faculties. The results found a significant difference in perception of students about instructional practices. So, it is concluded that faculty had a significant impact on students' perception regarding instructional practices. The research question; is there any significant difference in perception of students of each faculty about instructional practices? is answered in positive.

Table 5 Post Hoc Tests (Multiple Comparisons) for Instructional Practices with Respect to Faculty

\begin{tabular}{cccc}
\hline Mean & Mean & Mean Difference & P \\
\hline $\begin{array}{c}\text { Social Sciences } \\
\text { and Humanities } \\
3.55\end{array}$ & Sciences & .09922 & .136 \\
& 3.45 & & \\
& $\begin{array}{c}\text { Arabic and } \\
\text { Islamic Studies } \\
\text { 3.47 }\end{array}$ & .07197 & .504 \\
\hline
\end{tabular}

In table 5, Post-hoc comparison with Tukey HSD test revealed a mean score for faculty of Social Sciences and Humanities $(M=3.55)$ that was statistically significant and greater than other faculties $(\mathrm{M}=3.45,3.47,3.3)$ with $\mathrm{p}<0.05$.

ANOVA was applied to explore the impact of faculty on students' perception about instructional practices. A significant impact was found in students' perception in different faculties $\mathrm{F}(3,679)$ $=2.676, \mathrm{p}=.046$. So, the research question about the significant impact of faculty on students' perception was answered in positive. Post-hoc comparison with Tukey HSD test revealed a mean score for faculty of Social Sciences and Humanities $(M=3.55)$. So, it is concluded that students of faculty of Social Sciences and Humanities were found more satisfied as compared to the students of other faculties.

\section{Conclusions}

The present research sought to analyze students' perceptions about instructional practices at postgraduate level in Allama Iqbal Open University. By analyzing the literature and findings of the study, the following conclusions were drawn:

Students' perception regarding instructional practices was significant and positive. Male students tend to have positive perception regarding instructional practices than that of their counterparts in the sampled data. Students of faculty of Social Sciences and Humanities were found more satisfied as compared to the students of other faculties.

\section{Recommendations}

Based on the findings of the study major recommendations are as under:

Allama Iqbal Open University needs to improve its instructional practices, especially these practices: tutorials/face to face meetings assignments and assessment practices. 
There is a need to improve the instructional practices of AIOU to meet the need of the female students too, as they belong to marginalized group and are less reached as well as have less educational opportunities as compared to their male counterparts.

Students of M.Phil. and $\mathrm{PhD}$ programs should be facilitated in every perspective as they are the senior most students. Government of Pakistan and HEC should pay special attention toward their education. Most of them are working persons, having work and family responsibilities, so special attention and focus should be given while developing, designing, and implementing instructional practices for them. They fall in the category of adult as well as lifelong learners, so they may be specially facilitated.

There is a need to improve instructional practices for the students of faculty of sciences, faculty of Arabic and Islamic studies, and faculty of education, need revision and improvement to satisfy the open distance learners.

\section{References}

Aikael, J. (2010). Determinants of Rural Income in Tanzania: An Empirical Approach, Research Report 10 (4), Dar es Salaam: Research on Poverty Alleviation (REPOA).

Amey, F. L. \&Maroba, M. B. (2008). Botswana College of Distance and Open Learning (BOCODOL). In: Nonyongo. E. P., \&Ngengebule, A. T. (Eds.), Learner Support Services: Case Studies of DEASA Member Institutions, UNISA: University of South Africa, 10-23.

Asunka, S. (2008). Online Learning in Higher Education in Sub-Saharan Africa: Ghanaian University Students' Experiences and Perceptions, The International Review of Research in Open and Distance Learning, 9(3), 1-23.

Bhalalusesa, E. (2001). Supporting Women Distance Learners in Tanzania. Open Learning, 16(2): 155-168.

Bhalalusesa, E. P. (1998) Experiences of Learning at Distance at University Level in Tanzania: An Innovation in Learning, Dissertation (Doctor of Education), University of Bristol.

Boyd-Barrett, O. (2000). Distance Education Provision by Universities: How Institutional Context Affects Choices, Information, Communication \& Society, 3(4), 474-493.

Chadibe, I. A. (2002). Case Study Examining the Extent to which Urban and Semi-Rural Learning Centres are used as Support Systems for Distance Education Learners. UNISA, Pretoria.

Choudhry, A. H., Gujjar, A. A. \&Hafeez, M. R. (2008). Comparative Study of Student Support Services of AIOU and OUUK, Turkish Online Journal of Distance Education, 9 (1), 96117.

Daniel, J. (2007). The Expansion of Higher Education in the Developing World: What Can Distance Learning Contribute? CHEAInternationalCommission Conference, 1st February, Washington, DC. Retrieved May 29 2017from http://www.col.org/resources/speeches/2007presentations/Pages/2007-02-01.aspx

Daniel, J. (2010). Distance Education: Ends, Means, Opportunities \& Threats. Paper Presented in Shanghai International Forum on Lifelong Learning, May 19 to 21, Shanghai, China. 
De Hart, K. L \& Venter, J. M. P. (2013). Comparison of Urban and Rural Dropout Rates of Distance Students. Perspective in Education, 31 (1), 66-76.

Dzakiria, H. (2005) The Role of Learning Support in Open and Distance Learning: Learners Experiences and Perspectives, Turkish Online Journal of Distance Education, 6 (2), 95109.

Dzakiria, H. (2008). Students' Accounts of the Need for Continuous Support in a Distance Learning Programme, The Journal of Open and Distance Learning,23(2), 103-111.

Gatsha, G. \& Evans, R (2010.) Learning support: Perception and expressions of distance learners in Botswana. Progressio South African Journal for Open and Distance Learning Practice, 32(1) 155-169.

Gatsha, G. (2008). Tutoring Deeply Marginalised Distance Learners: Challenges and Achievements. Fifth Pan-Commonwealth Forum on Open Learning,13-17July, The University of London.

Khan, M. H. (2001) Rural Poverty in Developing Countries: Implications for Public Policy, USA: International Monetary Funds.

Krishnan, C. (2012), "Student support services in distance higher education in india: a critical appraisal". Pirdeaux, A (1989), "Support for Open and Distance Learners", Tait. A (ed), Conference Papers, International Conference in distance education and Open Learning, September 19-2, Cambridge, Downing College, 203-210.

Latif, L. A., Sungsri, S. \&Bahroom, R. (2009). Managing Retention in ODL Institutions: A Case Study on Open University Malaysia and SukhothaiThammathirat Open University, ASEAN Journal of Open and Distance Learning, 1(1), 1-10.

Lephalala, M. M. \&Makoe, M. (2012.) The Impact of Socio-Cultural Issues for African Students in the South African Distance Education Context, The Journal of Distance Education,26(1).

Macintyre, R. \& Macdonald, J. (2011). Remote from What? Perspectives of Distance Learning Students in Remote Rural Areas of Scotland, International Review of Research in Open and Distance Learning, 12(4), 1-16.

Mahai, L. (2012). ICT Based Support for Rural Students of the Open University of Tanzania: Perceptions, Challenges and Prospects. In: Amiel, T \& Wilson, B. (Eds.), Proceedings of World Conference on EducationalMultimedia, Hypermedia and Telecommunications, pp. 694-702.

Mbukusa, N. R. (2009). Barrier to Remote Rural Students Access to Distance Education Support Services Offered by the Centre for External Studies at the University of Namibia. Thesis (Doctor of Education), University of Namibia.

Mcharazo, A. A. S. \& Olden, A. (2000). Fulfilling the Learning Resource Requirements of Students at the Open University of Tanzania, Journal of Librarianship and Information Science, 32(4), 204-214.

Moore, M.G. \&Kearsley, G. (2012) Distance Education: A Systems View of Online Learning (3rd Edition), USA: Wadsworth 
Msuya, J. \&Maro, F. (2002) The Provision of Library and Information Services to Distance Learners: The Open University of Tanzania. Libri, 52, 183-191.

Rumble, G. (2000). Student Support in Distance Education in the 21st Century: Learning from Service Management, Distance Education, 21(2), 216-2351

Sahn, D. E. \&Stifel, S. C. (2003) Urban-Rural Inequalities in Living Standards in Africa, Journal of African Economies, 12(4), 564-597.

Sharma, D. P. (2011) Distance Education and Student Support Services, New Delhi-India: Omega Publications.

Simpson, O. (2000). Supporting Students in Open and Distance Learning. London:

Srivastava, M. \& Reddy, V. (2007) How Did They Study at a Distance? Experiences of IGNOU Graduates. International Journal of Distance Education Technologies, 5(3), 93102.

Sugata, M. (2008). Effects of Remoteness on the Quality of Education: A Case Study from North Indian Schools, Australasian Journal of Educational Technology, 24(2), 168-180.

Tait, A. (2000). Planning Student Support for Open and Distance Learning, Open Learning: The Journal of Open, Distance and e-Learning, 15(3), 287-299.

Tait, A., and Mills, R. (2002). Introduction. In A. Tait and R. Mills (Eds.) Rethinking Learner Support in Distance Education: Change and Continuity in an International Context (p.12). London: Routledge.

Ukpo, E. O. (2006). Support for Distance Learners in a Nigerian Distance Education Programme, The Journal of Open and Distance Learning, 21(3), 253-261.

UNESCO (2002). Open and Distance Learning: trends, policy and strategy consideration. 